\title{
Teaching Materials Service
}

Miss Tichenor is librarian, Ball State Teachers College, Muncie, Ind.

THE TEACHING MATERIALS SERVICE at 1 Ball State Teachers College is a department of the library. It is the campus center for the collection, preparation, and circulation of visual and auditory teaching aids. The problems involved in its administration and the problems of library administration are so similar that the affiliation between the two is a logical one. The field of visual and auditory aids is a limitless one on which we have as yet scarcely scratched the surface although we have done enough to see distinct results. Many of you may have accomplished far more in this line than we have done. If so, you appreciate the urge to extend which we feel.

What is teaching materials service? First of all, it is a highly organized collection of materials, other than printed books, which may be used to illustrate any phase of teaching. The collection includes a wide range of objects among which are samples of textiles, swatches of fabrics, charts, maps, pieces of wood carving, replicas, specimens of various kinds of glass and china, costume dolls, furniture in miniature, mounted birds and animals, pictures, slides, films, and projectors-in fact, anything that could be used to advantage in giving a child a clear conception of an object or an idea.

In the second place, the teaching materials service is a workshop. The workshop is available to individuals or to groups of students. The staff members give aid and advice and furnish materials to persons who are willing to donate to the department any worth-while project prepared there. This project may be any of a variety of pieces of work ranging from the mounting of an owl or an opossum to the creation of a puppet theatre or the preparation of a film.

What are the objectives of this department? The objectives which it strives to attain are of two kinds. One of them is campus economy. Making the collection and the services available to the whole campus cuts down drastically on the need for separate departmental duplications in equipment and material as well as in faculty requests for film loans from off the campus. Also, it is the center for the upkeep and repair of equipment. Furthermore, it gives a unity and permanence to all of the materials of a visual and auditory nature and it lends speed and easy availability to their use.

In the second place, it has a fine educational objective. This is neither the time nor the place for a presentation of the value of visual aids in teaching nor am I the person to present it. However, through the wise use of these materials the instructors are able to make the emotional appeal in teaching which turns classroom presentations into deep and lasting experiences. For this reason the collection constitutes a tremendous source of inspiration to faculty members and also to pro- 
spective teachers. Its location in juxtaposition to the book collection is a distinct advantage.

How was the service started? That was a difficult problem because both the clientele and collection had to be developed. Previous to the organization of this department quite a large amount of material had been collected here and there on the campus but each article was thought of as the possession of a specific department and its existence was scarcely known in the other departments. At the time the arts area, which is very active here, seemed to be the logical one to approach first. It grasped the opportunity eagerly and consequently many of the early holdings centered around the presentation of various phases of art. The home economics department too was an early user of these services. The idea of having a center for information about films and for borrowing them took hold readily. Last year in addition to the repeated use of films belonging to our small film library, the department borrowed 846 reels from other sources for the use of various instructors. At present the student-teachers as well as all the departments on the campus are making active use of the services of teaching materials service.

\section{Publicity}

What methods of publicity are used? In the first place, the director of teaching materials service makes as many personal contacts with faculty members as possible.

One faculty meeting, held in the department, was devoted to an explanation of the services and to an examination of the holdings of the department. College classes and classes in the campus laboratory school are encouraged to come in groups to investigate methods of supplementing their reading. Also the department arranges many exhibits which have real value for students. Some of them are elaborate, as for example, an extensive one on graphic arts, and some of them are more simple, involving materials which might easily be available in the ordinary classroom. Each week the director posts on strategic bulletin boards on the campus typed lists of the films which she is borrowing for certain days, so that they may serve as many different groups as possible.

Who administers this activity? It is in charge of a person who combines the fine background of wide teaching experience with excellent training as a museum worker. To our regret, we must admit that she does not have adequate assistance. If she kept abreast of the work which awaits her attention she would need a staff consisting at least of a cataloger, a reference worker, a carpenter, a seamstress, and several artists, not to mention scientists and a corps of boys for showing projections. In reality she manages to do an immense amount of good with only a very small part of that group. One of the regular library catalogers has helped her with her cataloging. From time to time she has had the services of a seamstress and a carpenter furnished by W.P.A. She has had also a young but able artist (with only high school training, however) and has had a great deal of student help. Among the qualifications for selecting student help are artistic and mechanical ability, an interest in elementary education, a quick and resourceful mind, a pleasant personality, a rather wide knowledge of some one or two subject fields, an interest in motion pictures, and, last but important, a capacity for carrying heavy projectors from one end of the campus to the other. 


\section{Services Given}

What services does teaching materials service give? First of all, from time to time the director teaches a four-quarterhour course entitled, "Audio-Visual Education." She selects and orders the new acquisitions. In addition, she directs all of the other activities of her department, a partial list of which includes workshop service; reference and loan work on the floor; a search through many film catalogs for appropriate films to meet the great number of faculty requests for loans from off-campus sources; training and scheduling student machine operators; training and directing students who work in the department; directing the preparation, upon request, of posters, charts, graphs, etc.; directing the preparation of materials for circulation including map mounting, picture framing, and dozens of other preparatory activities; work on the organization of a campus museum; making of a record of campus holdings of a similar nature in other departments, etc. Needless to say, only a few of these projects are being carried on at any one time. The director finds that one of the most timeconsuming activities in her day is taking care of visitors who come to study the work of the department and to profit by methods and activities in use there.

What groups are served by it? Unfortunately, at present, only the faculty and the students actually on the campus.
When the collection and the staff have grown to a point which makes a more extensive service feasible, it will be offered. The public elementary schools and high schools of Muncie are given fairly adequate service because our students do their student teaching in them.

Typical requests. It might be of interest to repeat here a few requests which are typical of the vast number presented in the department during the course of several days or a week. (I) A textile designed by Tony Sarg or Dorothy Trout or Ruth Reeves. (2) A piece of blown glass and a piece of molded glass. (3) A replica which will show how a medieval knight's armor actually looks. (4) A piece of hand-carved wood. (5) A doll clothed in the costume of a Swedish child. (6) A collection of fabrics arranged for use in teaching small children the difference between velvet and satin, linen and cotton, etc. (7) A collection of posters portraying graphically etiquette and manners for the adolescent. (8) A meteorite. (9) A framed picture to decorate the walls of a student's room. (10) A film or film strip which presents aviation.

Is the service worthwhile? How do we know? The answers to these questions are intangible and difficult. We know that it is worthwhile because of the volume which has developed and because of the expressions of appreciation which faculty members, students, and visitors make. 